\title{
The position of youth justice in EU criminal law: no game for kids
}

\author{
Jantien Leenknecht ${ }^{1}$ \& Johan Put ${ }^{2}$
}

\section{Introduction}

More than 1 million minors ${ }^{3}$ are exposed to criminal proceedings in the European Union (EU) every year. ${ }^{4}$ Some of them committed an offence beyond their national borders, as was the case with the murder of Joe Van Holsbeeck ${ }^{5}$ (Adam G. \& Mariusz O.) in 2006 and in the Eindhoven 'Kopschopper' case $^{6}$ from 2014. The occurrence of such cross-border cases is certainly becoming more common since the introduction of the internal market and its four fundamental freedoms. Not surprisingly, this leads to an increased attention to youth justice over the last decade, which is reflected in various European initiatives for criminological, policy and legal research. ${ }^{7}$ The lively debates on youth justice contrast sharply with the silence of the EU legislator in that field. No specific regulatory action can be noted at EU level that aims at facilitating a cooperation between Member States in youth justice. ${ }^{8}$

In criminal matters, the EU managed to establish several mechanisms to strengthen and facilitate judicial cooperation over the years, but does not clearly nor uniformly define the concepts of 'criminal matters', 'criminal proceedings', 'criminal responsibility', etc. in any of the cooperation instruments themselves. It is however important to know as to what the EU understands by the notion 'criminal' because Member States have developed specific rules in response to delinquent behaviour of minors, which are somewhat different from 'general' criminal law. ${ }^{9}$ The question arises whether the existing cooperation mechanisms only apply to 'adult' criminal matters or also include youth justice matters. This article therefore aims to find out whether a consistent and shared view exists on the meaning of the concept 'criminal' and to subsequently clarify to what extent the existing EU instruments in criminal matters also apply to juvenile offenders.

This article first briefly outlines the legal basis on which the EU competence in criminal matters is based and the resulting problem definition (chapter 2). It then distinguishes three types of instruments relevant to analyse the position of youth justice in EU criminal law: (1) mutual recognition instruments

\footnotetext{
${ }^{1}$ PhD Fellow of the Research Foundation Flanders (FWO) - KU Leuven, Institute for Social Law and Leuven Institute of Criminology. Corresponding author: jantien.leenknecht@kuleuven.be.

${ }^{2}$ Full professor University of Leuven (KU Leuven), Institute for Social Law and Leuven Institute of Criminology.

${ }^{3}$ The notions 'minor' and 'child' are used interchangeably in this contribution.

${ }^{4}$ Commission, 'Commission Staff Working Document - Impact Assessment accompanying the document Proposal for a Directive of the European Parliament and of the Council on procedural safeguards for children suspected or accused in criminal proceedings' SWD (2013) 480 final, 30.

${ }^{5}$ Two Polish boys aged 16 and 17 years, stabbed Joe to death at the central station in Brussels because he did not want to hand over his MP3 player. The boys fled to Poland and were surrendered to Belgium, provided that they could return to Poland in case a placement measure should be executed: http://news.bbc.co.uk/2/hi/europe/7632386.stm; Emmanuelle De Bock, 'Juridische obstakels voor uitlevering niet onoverkoombaar in zaak Joe Van Holsbeeck' (2006) iss. 129 Juristenkrant, 6.

6 Eight boys between 15 and 19 years of age, of whom 5 Belgians, kicked a 22-year-old man on his head several times after an out in Eindhoven. Two of them were finally surrendered to the Dutch court to be tried under Dutch juvenile criminal law: https://www.nrc.nl/nieuws/2013/08/15/geschrokken-van-hun-wangedrag-1283725-a694540.

${ }^{7}$ Examples of such initiatives are: 'My Lawyer, My Rights', 'Procedural Rights of Juveniles suspected or accused in the EU', 'Twelve', 'Children's Rights behind Bars', 'Juvenile Offenders Detention Alternative in Europe' (JODA)...

${ }^{8}$ UN Committee on the Rights of the Child, 'General comment No. 24 (2019) on children's rights in the child justice system', nr. 8, <http://docstore.ohchr.org/SelfServices/FilesHandler.ashx?enc=6QkG1d\%2fPPRiCAqhKb7yhsqlkirKQZLK2M58RF\%2f5F0vEnG3QGKUxFivhT oQfjGxYjV05tUAlgpOwHQJsFPdJXCiixFSrDRwow8HeKLLh8cgOw1SN6vJ\%2bf0RPR9UMtGkA4>: Child justice refers to the legislation, norms and standards, procedures, mechanisms and provisions specifically applicable to, and institutions and bodies set up to deal with, children considered as offenders. The UNCRC no longer used the notion 'juvenile justice', but acknowledges and encourages the trend towards using terms such as 'youth justice' and 'child justice'.

${ }^{9}$ Ido Weijers and Frank Imkamp, Jeugdstrafrecht in internationaal perspectief (Boom Juridische Uitgevers 2008 ) 337.
} 
with an age refusal ground, (2) mutual recognition instruments without an age refusal ground and (3) the procedural rights directives (chapter 3 ). The scope of application of each type of legislation is examined in chapter 4, based on three interpretations of the criminal concept: a classical, a formal and a substantive interpretation. The preparatory works of the EU criminal law instruments, the case law of the European Court of Justice, and the relevant leading legal doctrine on the subject matter are analysed to determine which interpretation the EU legislator is applying. Before the conclusion is formed, chapter 5 shows that the criminal concept is consistently interpreted in a substantive way outside the EU context, which raises some interesting issues.

\section{Youth justice as part of the EU competence in criminal matters?}

Following the special European Council in Tampere in $1999,{ }^{10}$ the principle of mutual recognition was introduced as the cornerstone of judicial cooperation in criminal matters in the $\mathrm{EU}^{11}$. For the first time, the European Community clearly departed from the traditional principle of national territoriality in criminal matters ${ }^{12}$ and the number of EU instruments increased significantly. Council Framework Decisions applying the principle of mutual recognition were issued to surrender procedures, ${ }^{13}$ freezing orders, ${ }^{14}$ financial penalties, ${ }^{15}$ confiscation orders, ${ }^{16}$ judgments imposing custodial sentences,${ }^{17}$ judgments concerning probation measures and alternative sanctions ${ }^{18}$ and decisions on supervision measures as an alternative to provisional detention ${ }^{19}$.

Ten years later, the judicial cooperation in criminal matters is communitarised by the Lisbon Treaty, but a definition of this domain is still lacking. ${ }^{20}$ The realisation of an area of freedom, security and justice is pursued by the Union, inter alia, through the mutual recognition of judgments in criminal matters and, if necessary, through the approximation of criminal law. ${ }^{21}$ The Lisbon Treaty also introduces directives instead of framework decisions as the common instrument to regulate judicial

\footnotetext{
${ }^{10}$ Vincent H. Glerum, 'De weigeringsgronden bij uitlevering en overlevering: Een vergelijking en kritische evaluatie in het licht van het beginsel van wederzijdse erkenning' (PhD thesis, Vrije Universiteit Amsterdam 2013), 116. The Cardiff European Council of 15 and 16 June 1998 nevertheless provided the impetus of the implementation of the Amsterdam Treaty and encouraged to identify the scope for greater mutual recognition of decisions in the fight against cross-border crime, but decided to devote a separate meeting to this matter: Cardiff European Council, Presidency Conclusions (SN 150/1/98 REV 1, 1998) paras 39 and 48.

${ }^{11}$ Hans van Landeghem, Gilles Van Cauteren and Daniel Van Dooren, 'Europees aanhoudingsmandaat' in Gert Vermeulen (ed), Aspecten van Europees formeel strafrecht (Maklu 2002), (165) 165.

12 Outcome of the European Council on 15/16 October in Tampere [2000] C 154/63, para 33; André Klip, European Criminal Law. An Integrative Approach (Intersentia 2009, vol 2), 330.

${ }^{13}$ Council Framework Decision 2002/584 of 13 June 2002 on the European arrest warrant and surrender procedures between Member States [2002] OJ L 190/1 (EAW FD).

${ }^{14}$ Council Framework Decision 2003/577 of 22 July 2003 on the execution in the European Union of orders freezing property or evidence [2003] OJ L 196/20 (Freezing orders FD).

${ }^{15}$ Council Framework Decision 2005/214 of 24 February 2005 on the application of the principle of mutual recognition to financial penalties [2005] OJ L 76/16 (Financial penalties FD).

${ }^{16}$ Council Framework Decision 2006/783 of 6 October 2006 on the application of the principle of mutual recognition to confiscation orders [2006] OJ L 328/59 (Confiscation orders FD).

${ }^{17}$ Council Framework Decision 2008/909 of 27 November 2008 on the application of the principle of mutual recognition to judgments in criminal matters imposing custodial sentences or measures involving deprivation of liberty for the purpose of their enforcement in the European Union [2008] OJ L 327/27 (Custodial sentences FD).

${ }^{18}$ Council Framework Decision 2008/947 of 27 November 2008 on the application of the principle of mutual recognition to judgments and probation decisions with a view to the supervision of probation measures and alternative sanctions [2008] OJ L 337/102 (Probation FD).

${ }^{19}$ Council Framework Decision 2009/829 of 23 October 2009 on the application, between Member States of the European Union, of the principle of mutual recognition to decisions on supervision measures as an alternative to provision detention [2009] OJ L 294/20 (European Supervision Order (ESO) FD).

${ }^{20}$ Sabine Gless, 'Police and Judicial Cooperation between the European Union Member States. Results and Prospects' in Cyrille Fijnaut and Jannemieke Ouderkerk (eds), The Future of Police and Judicial Cooperation in the European Union (Martinus Nijhoff Publishers 2010), (25) 26; Oana-Mariuca Petrescu, 'The European judicial cooperation in criminal matters in the light of the Lisbon Treaty' (2013) vol. 3 Challenges of the Knowledge Society 1208, 1212.

21 TFEU, Art 67 (3).
} 
cooperation in criminal matters, ${ }^{22}$ of which the directives regarding the European Protection $\operatorname{Order}^{23}$ and the European Investigation Order $^{24}$ are the first results.

To determine what elements (in casu of criminal matters) can be dealt with at EU level, the Treaties provide two inseparable principles, namely the principle of conferral and the principle of subsidiarity. Under the principle of conferral on the one hand, the EU can only act within the limits of the competences conferred upon it by the Member States in the Treaties to attain the objectives set out therein. ${ }^{25}$ For those powers that have not been transferred to the EU level, the Member States remain competent. Under the principle of subsidiarity on the other hand, the Union can only act in areas which do not fall within its exclusive competence if and so far as the objectives of the proposed action can be better achieved at EU level. ${ }^{26}$

Since no explicit ground of EU competence on youth justice can be found in the Treaties, one could argue that the principle of conferral is not satisfied and that the powers on youth justice proceedings therefore remain at Member State level. However, one might also argue that the competence in youth justice matters is part of the EU's competence in criminal matters, contained in articles 82 and 83 TFEU. Article 83 TFEU, which regulates substantial EU criminal law, is less important to analyse the crossborder cooperation in youth justice matters, since the description of offences in criminal justice is usually automatically adopted in youth justice. The way in which these offences are dealt with when committed by a minor, on the other hand, is way more relevant, which is why article 82 TFEU is of particular importance. This article regulates the procedural part of EU criminal law and describes two techniques to facilitate judicial cooperation in criminal matters. By virtue of the first paragraph, the EU can adopt rules and procedures that require the mutual recognition throughout the Union of all forms of judgments and judicial decisions and facilitate the cooperation between judicial authorities of the Member States (infra 3.1-3.3). The second paragraph allows the EU to establish minimum rules to facilitate such mutual recognition of judgments and judicial decisions, i.a. minimum rules concerning the rights of individuals in criminal procedures (infra 3.4) and the rights of victims of crime.

Even if youth justice is included in the shared competence on judicial cooperation in criminal matters that is conferred upon the EU, some authors argue that the subsidiarity principle is not being complied with. Compared to issues such as child-related immigration or trafficking, youth justice proceedings would not clearly demand a level of supranational coordination in the form of cross-border judicial cooperation. ${ }^{27}$ There are however definitely elements in the area of youth justice that would be better addressed at EU level, e.g. the execution of measures as close to home as possible, or tackling the use of minors in itinerant gangs. Youth justice proceedings have even led to cross-border cooperation between Member States in the past. ${ }^{28}$ It is therefore striking that so little attention is paid to youth justice in the development of judicial cooperation following the establishment of the internal market, which is reflected in the description of the EU competences. Although the Treaties determine the possibilities for EU action within the concept of 'criminal matters', they do not clarify what is to be understood by that criminal concept. As a consequence, it is unclear whether or not instruments adopted under its criminal law competence also apply to juvenile offenders. The next chapters try to

\footnotetext{
22 Labor Klimek, Mutual Recognition of Judicial Decisions in European Criminal Law (Springer 2017), 23.

${ }^{23}$ Directive 2011/99/EU of the European Parliament and of the Council of 13 December 2011 on the European protection order [2011] OJ L 338/2 (EPO Directive).

${ }^{24}$ Directive 2014/41/EU of the European Parliament and of the Council of 3 April 2014 regarding the European Investigation Order in criminal matters [2014] OJ L 130/1 (EIO Directive).

${ }^{25}$ Consolidated Version of the Treaty on European Union [2012] OJ C 115/13 (TEU), Art 5 (2).

${ }^{26}$ TEU, Art 5 (3).

${ }^{27}$ Helen Stalford, Children and the European Union (Hart Publishing 2012), 20; Dorris de Vocht, Michele Panzavolta, Miet Vanderhallen and Marc Van Oosterhout, 'Procedural Safeguards for Juvenile Suspects in Interrogations: A Look at the Commission's Proposal in Light of an EU Comparative Study' (2014) vol. 5 iss. 4 New Journal of European Criminal Law 480, 486.

28 Dorris de Vocht, Michele Panzavolta, Miet Vanderhallen and Marc Van Oosterhout, 'Procedural Safeguards for Juvenile Suspects in Interrogations: A Look at the Commission's Proposal in Light of an EU Comparative Study' (2014) vol. 5 iss. 4 New Journal of European Criminal Law 480, 486.
} 
find out the meaning of the 'criminal' concept by typifying the existing EU legislation in criminal matters.

\section{Three types of EU legislation in criminal law}

The EU legislation in criminal matters can for the purposes of this article be divided into three types: mutual recognition instruments with a (mandatory or optional) age refusal ground, mutual recognition instruments without an age refusal ground and the procedural rights directives.

\subsection{Mutual recognition instruments with an age refusal ground}

The principle of mutual recognition, as introduced by the Council of Tampere (supra 2), is not absolute. Most framework decisions and directives in criminal matters, in fact, contain some grounds for refusal to execute a foreign judicial decision. These refusal grounds are mostly related to fundamental concepts of domestic criminal justice systems ${ }^{29}$ in order to accommodate the Member States' concerns with regard to the principle of mutual recognition in criminal matters, more specifically their lack of mutual trust. ${ }^{30}$ After all, Member States have to recognise decisions which arise from the national law of other Member States and which, unlike harmonisation, are not based on a commonly negotiated standard. Apart from principles such as non bis in idem, amnesty, immunity and trial in absentia, the age of criminal responsibility also often constitutes a ground for refusal. Such a ground for nonexecution based on the age of the person concerned is introduced for the first time in the EAW FD ${ }^{31}$ : "the executing judicial authority has to refuse to execute the European arrest warrant if the person who is the subject of the warrant may not, owing to his age, be held criminally responsible for the acts on which the arrest warrant is based under the law of the executing State".$^{32}$ As a consequence, the execution of the cooperation measure depends on the age of criminal responsibility of the executing Member State. It is very clear that the political sensitivity regarding the criminal responsibility age has led to this ground of refusal and therefore was chosen over the principle of mutual recognition. Despite the general agreement on the fact that not every minor may be surrendered to a foreign country just like that, finding a common age limit from which minors could be surrendered was quickly off the table. Consequently, Member States accept or refuse the European arrest warrant in accordance with their own age of criminal responsibility. ${ }^{33}$

In most other instruments on mutual recognition in criminal matters, the same age refusal ground returns, albeit being optional instead of mandatory. There are more specifically five instruments in EU criminal law that provide for the possibility for Member States to set aside the principle of mutual recognition based on the age of the person concerned: article $7(1)(f)$ of the financial penalties FD, article $9(1)(g)$ of the custodial sentences FD, article $11(1)(g)$ of the probation FD, article $15(1)(g)$ of the ESO FD and article 10 (1) (h) of the EPO Directive. It is not always clear why an age refusal ground is included in one mutual recognition instrument and not in the other, or why it is optional instead of mandatory. In its Green Paper on the approximation, mutual recognition and enforcement of criminal sanctions, the Commission suggested to only consider the grounds for refusal provided by the EAW FD. ${ }^{34}$ The Commission thereby acknowledged the possibility that not all refusal grounds are

\footnotetext{
${ }^{29}$ Proposal for a Council Framework Decision on the European arrest warrant and the surrender procedures between the Member States [2001] OJ C 332 E/305, Art 27 and its explanatory memorandum.

${ }^{30}$ Valsamis Mitsilegas, EU Criminal Law (Hart Publishing 2009), 130.

${ }^{31}$ Hans van Landeghem, Gilles Van Cauteren and Daniel Van Dooren, 'Europees aanhoudingsmandaat' in Gert Vermeulen (ed), Aspecten van Europees formeel strafrecht (Maklu 2002), (165) 169.

${ }^{32}$ EAW FD, Art 3 (3).

${ }^{33}$ Commission, 'Communication to the Council and the European Parliament - Mutual Recognition of Final Decisions in Criminal Matters' COM (2000) 495 final, 10; Case C-367/16 Piotrowski [2018] ECR I-104/7, para 30.

${ }^{34}$ Commission, 'Green Paper on the approximation, mutual recognition and enforcement of criminal sanctions in the European Union' COM (2004) 334 final, 60-61.
} 
transposable, given the fact that the principle of mutual recognition of foreign judicial decisions operates primarily for the benefit of the person concerned..$^{35}$

\subsection{Mutual recognition instruments without an age refusal ground}

There are five mutual recognition instruments that do not have a ground for refusal based on the age of the person concerned: (1) the freezing orders FD, which will be replaced by (2) the ElO Directive and (3) the Regulation 2018/1805 on the mutual recognition of freezing orders and confiscation orders; ${ }^{36}$ (4) the confiscation orders FD, which will also be replaced by the freezing orders and confiscation orders Regulation; and (5) the Council Framework Decision 2009/299 of 26 February 2009 amending certain Framework Decisions thereby enhancing the procedural rights of persons and fostering the application of the principle of mutual recognition to decisions rendered in the absence of the person concerned at the trial. ${ }^{37}$ The latter does however not make any changes regarding the age refusal ground and is moreover a procedural rights instrument rather than a mutual recognition instrument; therefore, it will not be further discussed here.

\subsection{The procedural rights directives, in particular the Children Directive}

The third and final category consists of the procedural rights directives, which are the result of the 'Roadmap for strengthening the procedural rights of suspected or accused persons in criminal proceedings' ('the Procedural Rights Roadmap'), adopted by the Council of the European Union on 30 November 2009. ${ }^{38}$ The purpose of this EU programme is to strengthen mutual trust between Member States in each other's criminal justice systems and consequently to improve mutual recognition of decisions in criminal matters, by establishing common minimum standards that regulate certain aspects of criminal procedure. ${ }^{39}$ Under the Procedural Rights Roadmap, six directives have been established ${ }^{40}$ of which the Children Directive 2016/800 is the most interesting to explore for the purposes of this article, since it is precisely at the interface between criminal justice and children's rights. The Children's Directive is the first legislative instrument in EU criminal law that contains binding provisions which explicitly and exclusively concern juvenile offenders. It applies to children who are suspects or accused persons in criminal proceedings or who are subject to European arrest warrant proceedings. ${ }^{41}$ The Directive defines children as persons below the age of $18^{42}$, thereby confirming that there is a European consensus on the concept of 'a child'. What is to be understood by the term 'criminal proceedings' is, in contrast, not defined by any operative provision, ${ }^{43}$ even though the

\footnotetext{
35 Ibid.

${ }^{36}$ Regulation 2018/1805 of the European Parliament and of the Council of 14 November 2018 on the mutual recognition of freezing orders and confiscation orders [2018] OJ L 303/1 (freezing orders and confiscation orders Regulation).

${ }^{37}$ Council Framework Decision 2009/299 amending Framework Decisions 2002/584, 2005/214, 2006/783, 2008/909 and 2008/947, thereby enhancing the procedural rights of persons and fostering the application of the principle of mutual recognition to decisions rendered in the absence of the person concerned at the trial [2009] OJ L 81/24 (in absentia FD).

${ }^{38}$ Resolution of the Council of 30 November 2009 on a Roadmap for strengthening procedural rights of suspected or accused persons in criminal proceedings [2009] OJ L 295/1.

${ }^{39}$ Children Directive, recital 2.

${ }^{40}$ (1) Directive 2010/64/EU of the European Parliament and of the Council of 20 October 2010 on the right to interpretation and translation in criminal proceedings [2010] OJ L 280/1; (2) Directive 2012/13/EU of the European Parliament and of the Council of 22 May 2012 on the right to information in criminal proceedings [2012] OJ L 142/1; (3) Directive 2013/48/EU of the European Parliament and of the Council of 22 October 2013 on the right of access to a lawyer in criminal proceedings and in European arrest warrant proceedings, and on the right to have a third party informed upon deprivation of liberty and to communicate with third persons and with consular authorities while deprived of liberty [2013] OJ L 294/1; (4) Directive 2016/343 of the European Parliament and of the Council of 9 March 2016 on the strengthening of certain aspects of the presumption of innocence and of the right to be present at the trial in criminal proceedings [2016] OJ L 65/1; (5) Directive 2016/800 of the European Parliament and of the Council of 11 May 2016 on procedural safeguards for children who are suspects or accused persons in criminal proceedings [2016] OJ L 132/1 (Children Directive); (6) Directive 2016/1919 of the European Parliament and of the Council of 26 October 2016 on legal aid for suspects and accused persons in criminal proceedings and for requested persons in European arrest warrant proceedings [2016] OJ L 297/1.

${ }^{41}$ Children Directive, Art 1.

${ }^{42}$ Children Directive, Art 3 (1).

${ }^{43}$ Renaud Colson and Stewart Field (eds), EU criminal justice and the challenges of diversity: legal cultures in the area of freedom, security and justice (Cambridge University Press 2016) 154.
} 
Children Directive was the ideal opportunity to sharpen the criminal justice/juvenile justice relationship. It is however crucial for Member States to know in which situations the transposition of the Directive is mandatory, in order to be compliant with its provisions (which should have been reached by 11 June 2019).

Although all six directives have the same scope, namely criminal proceedings,

\section{Scope of application of the three types of EU legislation in criminal matters}

\subsection{Three possible interpretations of the scope of application of EU legislation in criminal matters}

This chapter tries to provide insight into the scope of the three aforementioned types of EU legislation in criminal matters by unravelling three possible interpretations of the notion 'criminal', which we will call the classical, the formal and the substantive interpretation. ${ }^{44}$

The classical interpretation assumes that the concept 'criminal' only includes legislation and proceedings that are generally applicable to adults who commit an offence. This interpretation is therefore inevitably linked to the notion 'age of criminal majority' (ACM), which is the age from which on persons are in any case subject to the general criminal law. ${ }^{45}$ The ACM is in almost all Member States fixed at 18 years and thus the counterpart of the concept 'minor'. ${ }^{46}$ As a result, minors are excluded from the notion 'criminal' under the classical interpretation, save when a Member State has a mechanism to transfer minors to adult courts ('waiver') for particularly serious offences, or has fixed its ACM below the common age of $18,{ }^{47}$ in which case minors are fully subject to the ordinary criminal law.

The second, and intermediate, interpretation is the formal interpretation. This interpretation determines the meaning of the notion 'criminal' according to the label given to the matter by the domestic legislation of the Member State concerned. This label can be deduced, for example, from the fact that a Member State calls it youth justice system 'juvenile criminal law' or from the fact that the youth justice rules are included in the general penal code. So when a Member State attributes criminal aspects to its youth justice system, this national classification is adopted at EU level.

A substantive interpretation, finally, adopts a broader approach and goes beyond the national classification. It considers any system that provides an offence oriented reaction to a committed crime as criminal, regardless of how that system is officially labelled. In that view, youth justice is nonetheless considered as criminal, because its reactions to delinquent behaviour can be very far-reaching and intrusive in the life of the minor concerned, just like 'pure' criminal penalties can be in the case of adults.

\subsection{Scope of application of mutual recognition instruments with an age refusal ground}

\footnotetext{
${ }^{44}$ The interpretations are derived from the distinction between the formal and substantive criminal nature of youth justice systems in Michele Panzavolta, Dorris de Vocht, Marc Van Oosterhout and Miet Vanderhallen (eds), Interrogating Young Suspects: Procedural Safeguards from a Legal Perspective (Intersentia 2015) 374.

45 Don Cipriani, Children's Rights and the Minimum Age of Criminal Responsibility: A Global Perspective (Ashgate 2009), preface; Case C367/16 Piotrowski [2018] ECR I-104/7, Opinion AG Bot, para 31.

${ }^{46}$ See findings in Jantien Leenknecht, Johan Put and Katrijn Veeckmans, 'Age limits in youth justice: a comparative and conceptual analysis' (2020) Erasmus Law Review (forthcoming).

${ }^{47}$ In Portugal, for instance, juvenile offenders aged 16 and over are tried on the basis of the provisions of the general Criminal Code by courts of general jurisdiction, whereas the ACM in Poland is fixed at 17 years. See respectively: Yanna Papadodimitraki, 'Minimum Age of Criminal Responsibility (MACR) - Comparative Analysis International Profile - Portugal' (Centre for Youth and Criminal Justice, March 2016), 2; Committee on the Rights of the Child, 'Initial reports of States parties due in 1992: Portugal' CRC/C/3/Add.30, no. 198; Josine Junger-Tas and Scott H. Decker (eds), International Handbook of Juvenile Justice (Springer 2006) 357; Frieder Dünkel, Joanna Grzywa, Philip Horsfield and Ineke Pruin (eds), Juvenile Justice Systems in Europe: Current Situation and Reform Developments, vol 2 (Forum Verlag 2010$) 1004$.
} 
In the formation of the EAW FD, the age refusal ground was introduced by the European Parliament as an amendment to the proposal of the Commission. ${ }^{48}$ The justification given was that the executing Member State should have the possibility to refuse to execute the arrest warrant when the requested person is considered to be a minor in that state. ${ }^{49}$ This wording is usually associated with the age of criminal majority (cf. 4.1), whereas the scope of application of mutual recognition instruments with an age refusal ground depends on the age of criminal responsibility of the executing Member State (cf. 3.1). Moreover, whereas the European Parliament formulated the refusal ground as optional, it appears without explanation as a mandatory refusal ground in the final adoption by the Council. ${ }^{50}$ The significance of the age refusal ground has thus been unclear from the outset.

\subsubsection{European Commission excludes classical interpretation as possible interpretation}

In order to tackle some of the most common issues, the Commission recently issued a handbook on how to issue and execute a European arrest warrant. ${ }^{51}$ With regard to the age refusal ground, the handbook states that it applies if, in the executing Member State, the requested person might only face civil or administrative proceedings, but not criminal, due to his or her age. ${ }^{52}$ In other words, minors can only be surrendered if they are subject to criminal proceedings. Despite the importance of the clarification, it is not specified whether judicial youth justice proceedings are considered to be (a type of) criminal proceedings. The wording of the Commission suggests that only 'pure' civil and administrative proceedings, without criminal elements, justify a refusal to surrender a minor. It is therefore unlikely that the age refusal ground also applies to youth justice proceedings and that only minors who are subject to adult criminal proceedings can be surrendered (classical interpretation). The question left is therefore whether all youth justice proceedings lead to a prohibition to refuse a surrender (substantive interpretation), or only the ones that are labelled as 'criminal' according to the executing Member State (formal interpretation). However, the Commission handbook remains ambiguous at that point.

\subsubsection{The Piotrowski case indicates a formal interpretation}

Due to the persistent lack of clarity regarding the age refusal ground, ${ }^{53}$ the Brussels' Court of Appeal submitted a request for a preliminary ruling to the European Court of Justice (ECJ) to know what is meant by the wording of "the person who may not, because of his age, be held criminally responsible", as laid down in Article 3 (3) EAW FD. ${ }^{54}$ The two relevant questions that the Court of Appeal asked were

(1) whether the age refusal ground only grants surrender in respect of persons who have already attained the age of majority under the law of the executing Member State, or if it also allows the surrender of minors who can be held criminally responsible from a certain age under the national rules;

(2) whether the age refusal ground means that the executing Member State should carry out an assessment in abstracto on the basis of the criterion of the age from which someone can be regarded as criminally responsible, without taking into account any possible further conditions, or if an assessment in concreto on a case-by-case basis is necessary in order to

\footnotetext{
${ }^{48}$ European Parliament, 'Report of 14 November 2001 on the Commission proposal for a Council framework decision on the European arrest warrant and the surrender procedures between the Member States' A5-0397/2001, Amendment 73.

${ }^{49}$ European Parliament, 'Report of 14 November 2001 on the Commission proposal for a Council framework decision on the European arrest warrant and the surrender procedures between the Member States' A5-0397/2001, 44.

50 Proposal for a Council Framework Decision on the European arrest warrant and the surrender procedures between the Member States [2001] OJ C $332 \mathrm{E} / 305$, explanatory memorandum of article 27.

${ }^{51}$ Commission, 'Commission Notice - Handbook on how to issue and execute a European arrest warrant' 2017/C 335/01.

${ }^{52}$ Commission, 'Commission Notice - Handbook on how to issue and execute a European arrest warrant' 2017/C 335/01, 30.

${ }^{53}$ In 2013, the Belgian Court of Cassation rule two contradictory judgments on the age refusal ground: Cass 6 February 2013, AR P.13.0172.F, Tijdschrift voor Jeugd en Kinderrechten 2013, iss. 2, 176 and Cass. 11 June 2013, AR P.13.0780.N, Tijdschrift voor Jeugd en Kinderrechten 2013, iss. 3, 295. In 2016, the Court of Cassation settled the issue by ruling that a minor can only be surrendered if youth justice measures have already been taken or if the minor committed one of the serious crimes as listed in article 57 bis of the Youth Protection Act: Cass. 11 May 2016, AR P.16.0545.F, Tijdschrift voor Jeugd en Kinderrechten 2016, iss. 4, 352.

${ }^{54}$ Case C-367/16 Piotrowski [2018] ECR I-104/7.
} 
surrender a minor, where the same conditions for criminal responsibility must be met as the ones that apply to the nationals of the executing Member State..$^{55}$

As far as the first question is concerned, the ECJ deduces from the wording and the purpose of article 3 (3) EAW FD that not all minors are excluded from surrender, but only those minors who, under the law of the executing Member State, have not reached the age required to be regarded as criminally responsible. ${ }^{56}$ By explicitly stating that this exception was not meant to exclude minors in general and by consistently using the term 'criminal responsibility' instead of '(criminal) majority', it is clear that the ECJ goes beyond the classical interpretation, in which in general only adults could be surrendered.

How much the ECJ exactly goes beyond the classical interpretation, is unclear because the judgment does not express what is exactly to be understood by 'criminal responsibility', despite the impetus given in AG Bot's opinion. He makes a distinction between the age of criminal majority (ACM) and the age of criminal responsibility, by defining the ACM as the age from which a person is subject to the general law of criminal responsibility, and the age of criminal responsibility as the age from which a minor may be held criminally responsible for offences which they commit. ${ }^{57}$ This is indeed a fundamental distinction in youth justice literature and a good foundation from which to build further reasoning. However, not only can AG Bot's description of the notion 'criminal responsibility' hardly be called a definition, since both the words 'criminal' and 'responsible' are used, the ECJ does also not apply the distinction carefully in its judgment, despite its reference to it. ${ }^{58}$ First of all, the ECJ describes the argument of the Belgian Public Prosecutor as "while the age of criminal responsibility is 18, a minor over the age of 16 may nonetheless be held criminally responsible (...)" ${ }^{59}$ Whereas the age of 18 would be the ACM according to AG Bot's description, the ECJ thus uses the notion of 'criminal responsibility' for the age limit of 18. Although this could be a negligent adoption of the public prosecutor's wording, the ECJ furthermore repeats in its findings a few times that the age refusal ground applies if a minor has not reached the minimum age from which he may be regarded as criminally responsible. ${ }^{60}$ One could see this as an indication that criminal responsibility should be understood as the situations in which a minor could potentially be subject to adult criminal law, such as the transfer of a minor to adult court in serious cases. In that case, being criminal responsible is the same as being subject to an exceptional lowering of the $\mathrm{ACM}$, resulting in a toned-down version of the classical interpretation.

AG Bot furthermore elaborates on the specific nature of youth justice, which he describes as criminal law applicable to minors ('jeugdstrafrecht' in the Dutch translation) ${ }^{61}$ and therefore definitely sees youth justice as a type of criminal law. He more specifically acknowledges that youth justice systems use the traditional mechanisms of criminal responsibility, but also changes them with substantive features that were introduced on the basis of the underlying principle that education should be preferred to punishment. ${ }^{62}$ As a consequence, youth justice systems have a diversification of the range of available responses in which an educational measure can be imposed as a criminal punishment. ${ }^{63}$ The conclusion of AG Bot is therefore that surrender of a minor must be refused when he is too young for a penalty to be imposed, even one consisting in an educational measure, in the executing Member

\footnotetext{
${ }^{55}$ Case C-367/16 Piotrowski [2018] ECR I-104/7, para 26.

${ }^{56}$ Case C-367/16 Piotrowski [2018] ECR I-104/7, para 29-30; Eurojust, 'Case Law by the Court of Justice of the EU on the European Arrest Warrant' (2018) < $\quad$ www.eurojust.europa.eu/doclibrary/Eurojustframework/caselawanalysis/Case\%20Law\%20by\%20the\%20Court\%20of\%20Justice\%20of\%20the\%20European\%20Union\%20on\%20the\%2 OEuropean\%20Arrest\%20Warrant\%20(October\%202018)/2018-10 EAW-case-law EN.pdf> accessed 6 August $2019,31$.

57 Case C-367/16 Piotrowski [2018] ECR I-104/7, Opinion AG Bot, para 31.

${ }^{58}$ Case C-367/16 Piotrowski [2018] ECR I-104/7, para 31. The ECJ more specifically refers to Case C-367/16 Piotrowski [2018] ECR I-104/7, Opinion AG Bot, para 32: "It is thus evident that the EU legislature, in laying down in this provision that the judicial authority of the executing Member State must refuse to surrender to the authorities of the issuing Member State a person who 'may not, owing to his age, be held criminally responsible' for his acts, was not referring to persons who have not yet reached the age of criminal majority, but to minors who cannot be held criminally responsible under the law of the executing Member State" (emphasis added).

${ }^{59}$ Case C-367/16 Piotrowski [2018] ECR I-104/7, para 18.

$60 \mathrm{Ibid}$, para 31 and 42.

${ }^{61}$ Case C-367/16 Piotrowski [2018] ECR I-104/7, Opinion AG Bot, para 35 and 46.

62 Ibid, para 36, 37 and 41.

63 Ibid, para 49 and 53
} 
State ${ }^{64}$ In other words, from the age at which an educational measure can be imposed on a minor as a punishment for a committed crime, a minor can be surrendered on the basis of article 3 (3) EAW FD. A refusal of surrender is therefore only allowed when the measure taken should be understood purely as an educational measure, as opposed to a combination of punishment and education. ${ }^{65}$ This corresponds with the established ECJ case law that exceptions to the principle of mutual recognition should be interpreted strictly. ${ }^{66}$

Despite the refreshing clarification that educational measures can also be qualified as penalties, which could be an indication of a substantive interpretation, AG Bot does not provide characteristics as to what constitutes a penalty or punishment, and consequently criminal responsibility, nor indicates what part the ECJ could play in this. On the contrary, he refers to the notion 'criminal responsibility' as "however that expression is defined" and states that "we find ourselves in area (...) that leaves each Member State free to choose the method by which it will determine the criminal responsibility of minors, while requiring it to recognise the method chosen by the other Member States" ${ }^{67}$ He thus applies the principle of mutual recognition to the national requirements of criminal responsibility as well, so that national youth justice systems can allow themselves to refuse the surrender of a juvenile offender when they do not define their educational measures as penalties. AG Bot therefore approaches the criminal concept on the basis of the formal interpretation.

As with the distinction between the age of criminal responsibility and the $A C M$, the $E C J$ is also much less explicit and consistent than AG Bot in its statements on the notion of 'criminal responsibility'. It for instance reformulates criminal responsibility as being the subject of any (criminal) prosecution or conviction, ${ }^{68}$ but one time requires the criminal nature of that prosecution or conviction, ${ }^{69}$ and another time does not. ${ }^{70}$ The ECJ further states that Member States, in the absence of harmonisation in this field, are given the discretion to determine the minimum age from which a person satisfies the requirements to be regarded as criminally responsible for his acts. ${ }^{71}$ Whereas it is obvious that the ECJ requires Member States to mutually recognise each other's minimum age of criminal responsibility (MACR, infra 5), it is less clear what requirements the ECJ is referring to. However, based on the wording of Article 3 (3), the preparatory works and the legislative context of the EAW FD, the ECJ deduces that the age refusal ground only excludes minors who, on account of their age, cannot be made the subject of any criminal proceedings or a conviction under the law of the executing Member State. ${ }^{72}$ So not only does the ECJ itself not provide criteria that determine when someone is considered to be criminally responsible, the only references made are to the legislation of the executing Member State. The court therefore seems to follow the reasoning of AG Bot, namely that national requirements of criminal responsibility should be mutually recognised by the Member States as well and that only minors who are subject to proceedings that are considered to be criminal according to the national legislation of the executing Member State, can be surrendered. Although the ECJ takes no clear stand, it can be concluded that it adopts a formal interpretation regarding the criminal concept, albeit implicitly. Since the age refusal ground in the other mutual recognition instruments with such a refusal ground is formulated in the same way, this interpretation of the ECJ will also apply to these instruments. $^{73}$

The ECJ's answer to the second preliminary question, on the other hand, is much more straightforward and implies that the executing Member State should carry out an assessment in abstracto. The ECJ

\footnotetext{
64 Ibid, para 59

65 Ibid, para 50

${ }^{66}$ Case C-367/16 Piotrowski [2018] ECR I-104/7, para 48.

${ }^{67}$ Case C-367/16 Piotrowski [2018] ECR I-104/7, Opinion AG Bot, para 54 and 59.

${ }^{68}$ Case C-367/16 Piotrowski [2018] ECR I-104/7, para 30, 34 and 42.

${ }^{69}$ Ibid, para 30 and 34.

70 Ibid, para 42-43.

71 lbid, para 30

$72 \mathrm{Ibid}$, para 30, 34, 42 and 51.

${ }^{73}$ Frederic Vroman, 'Het Europees aanhoudingsbevel en de passieve overlevering door België van minderjarigen. Het antwoord van het Hof van Justitie: zestienjarigen kunnen altijd worden overgeleverd" (2018) 2 Tijdschrift voor Strafrecht 110, 113.
} 
more specifically concludes that the executing Member State has to check only whether the person concerned has reached the age of criminal responsibility of the executing Member State, and not consider any other additional conditions with regard to the circumstances of the individual that are required in the that Member State for the prosecution and conviction, and consequently criminal responsibility, of a minor. ${ }^{74}$ Although this answer does not provide any new insight into the criminal concept, it confirms the above findings. On the one hand, the ECJ excludes the possibility of a substantive interpretation by merely answering this question. It would not make sense to answer the second question if the answer to the first question would be that the age of criminal responsibility should be understood as the age from which on an offence-oriented reaction can be imposed on a person for his criminal behaviour. In that case, any youth justice system would qualify as holding a minor criminal responsible and would therefore not be allowed to refuse the surrender of a minor. Whether the refusal should be based on an in abstracto or in concreto assessment would thus not even matter and the ECJ would have been able to close the case after answering the first question. On the other hand, the ECJ confirms in this answer that it adopts a formal interpretation. It bases its decisions on the wording of article 3 (3) EAW FD, which does not describe other conditions of the executing Member State to be taken into account than its age of criminal responsibility. ${ }^{75}$ Moreover, if one were to do so anyway, it would amount to a re-examination of the assessment by the issuing Member State, which would undermine the principle of mutual recognition and its objective of facilitating an accelerating judicial cooperation in criminal matters. ${ }^{76}$ In other words, the ECJ requires the executing Member State to accept the assessment of the criminal responsibility of the minor according to the national conditions of the issuing Member State instead of substituting its own assessment based on its own national conditions, which is inherent to the formal interpretation.

\subsection{Scope of application of mutual recognition instruments without an age refusal ground}

When no age refusal ground is contained in a mutual recognition instrument, we must fall back on the general scope of those EU instruments in criminal matters. Although the EU legislator itself declares that 'proceedings in criminal matters' is an autonomous concept in EU law, ${ }^{77}$ he failed to give a binding interpretation to that concept so far. Non-binding policy documents, preparatory works and recitals are, in the meantime, the only resources to uncover the scope of mutual recognition instruments in criminal matters with regard to minors.

\subsubsection{European Commission excludes classical interpretation as possible interpretation?}

In 2000, the Commission issued a communication on the mutual recognition of final decisions in criminal matters, which was issued in order to contribute to the implementation of the Tampere Council Conclusions. ${ }^{78}$ Concerning the scope with regard to the offender, the Commission states that decisions dealing with minors should be excluded from the scope of mutual recognition in criminal matters. ${ }^{79}$ It argues that the great variety in rules on the treatment under criminal law of minors among the Member States would make it too difficult to recognise such decisions. ${ }^{80}$ This point of view is later on repeated in the 2004 Commission's Green Paper on the approximation, mutual recognition and enforcement of criminal sanctions in the European Union. ${ }^{81} \mathrm{It}$ more specifically states that due to the wide variety in the national rules of criminal law relating to the treatment of minors, it might be

\footnotetext{
${ }^{74}$ Case C-367/16 Piotrowski [2018] ECR I-104/7, para 62.

$75 \mathrm{Ibid}$, para 51.

76 lbid, para 52-53.

${ }^{77}$ Freezing orders and confiscation orders Regulation, recital 13.

${ }^{78}$ Commission, 'Communication to the Council and the European Parliament - Mutual Recognition of Final Decisions in Criminal Matters' COM (2000) 495 final, 3

${ }^{79}$ Commission, 'Communication to the Council and the European Parliament - Mutual Recognition of Final Decisions in Criminal Matters' $\operatorname{COM}(2000) 495$ final, 10.

$80 \mathrm{lbid}$.

${ }^{81}$ Commission, 'Green Paper on the approximation, mutual recognition and enforcement of criminal sanctions in the European Union' COM (2004) 334 final.
} 
preferable to exclude judgments concerning them from the scope of any mutual recognition rules. ${ }^{82}$ At first sight, these statements seem to indicate a classical interpretation, because they suggest that the principle of mutual recognition in criminal matters should only be applicable to ordinary criminal proceedings. However, the Commission is not describing the situation de lege lata, but is answering the question how the mutual recognition principle should be implemented in EU criminal law. The Commission more specifically seems to anticipate the introduction of grounds for refusal based on the age of the person concerned. From this point of view, adopting the classical interpretation makes no sense: if minors would already be excluded from the scope of mutual recognition in criminal matters altogether, introducing an age refusal ground is pointless. In other words, these statements could also be considered to indicate that youth justice legislation needs active exclusion by the EU legislator to not fall under the scope of mutual recognition in criminal matters. If such exclusion is lacking, they could conversely be considered to be included in the scope.

\subsubsection{No general binding definition of the criminal concept}

The question that arises next is whether the principle of mutual recognition only applies to youth justice legislation that is 'formally' criminal or to all types of youth justice legislation, i.e. provisions specifically applicable to crimes committed by minors (supra footnote 8). Interesting in that regard is the general definition of 'material criminal law' that was given by the Commission in its 2000 communication:

"(Material) criminal law is traditionally understood as the rules whereby a state foresees sanctions as a reaction to behaviour that it deems incompatible with its social norms, for the purpose of deterring the offender from repeating his offences and deterring others from committing similar acts. Recently, this understanding has widened to include elements of rehabilitation (for example, drug treatment orders)." ${ }^{\prime 83}$

The Commission thus points out that the criminal law concept has evolved over the years and is no longer merely aims at deterrence, but also at rehabilitation. That finding is relevant with regard to youth justice systems, which tend to focus primarily on reintegration and re-education. Moreover, youth justice measures are reactions to behaviour that is incompatible with a Member State's social norms, which fits the Commission's description of what criminal law is. On the basis of the definition above, it could therefore be suggested that the Commission rather applies a substantive interpretation and would consider youth justice measures as part of the criminal law concept.

However, there are a number of reasons that weaken the importance of the Commission's definition. First of all, the fact that the Commission suggests that criminal matters now also include rehabilitation measures opens up possibilities for alternatives to deterring penalties within criminal law itself. Whether youth justice measures are covered by the notion as well is much less likely, since youth justice is an alternative to criminal law as such.

Furthermore, the European Parliament's committee on Citizens' Freedoms and Rights, Justice and Home Affairs has expressed a different opinion on the meaning of 'criminal matters' in its reaction on the Commission's communication. It more specifically argues that the notion 'criminal matters' should be linked to a 'formal' definition of criminal provisions, namely to positive criminal law. ${ }^{84}$ As a consequence, criminal matters consist of provisions that connect penalties to prohibited acts whereby both the provision and the penalty are qualified as 'criminal' under the legislation of the Member States. ${ }^{85}$ The committee thus makes the interpretation of the concept of 'criminal matters' dependent on the national rules on criminal law, which corresponds to the formal interpretation. From that point

\footnotetext{
82 Ibid, 59.

${ }^{83}$ Commission, 'Communication to the Council and the European Parliament - Mutual Recognition of Final Decisions in Criminal Matters' $\operatorname{COM}(2000) 495$ final, 5.

${ }^{84}$ Committee on Citizens' Freedoms and Rights, Justice and Home Affairs, 'Report of 26 April 2001 on the Commission communication to the Council and the European Parliament on the mutual recognition of final decisions in criminal matters' A5-0145/2001, 15.

85 lbid.
} 
of view, national youth justice provisions and youth justice measures would only be considered as criminal law and criminal penalties at EU level if they are also qualified as 'criminal' at national level.

It is somewhat confusing that the committee subsequently adds that its definition of 'criminal matters' is not affected by who applies the provisions of criminal law, nor how criminal proceedings or investigations are resolved nor the legal nature of the person who is subject to the criminal laws. ${ }^{86}$ Although this description seems rather typical of the substantive interpretation at first sight, the committee clearly considers the modalities of by who/how/to whom the provisions are applied irrelevant only after it is established that those provisions are labelled as 'criminal' under the national legislation.

This discussion dates back to 2000-2001 and could be considered as important in determining the fundamental outlines and the future possibilities for mutual recognition instruments in criminal matters. Although it did result in a proposal on procedural safeguards for suspects and defendants in criminal proceedings throughout the European Union, ${ }^{87}$ no final opinion was expressed on the meaning of 'criminal matters'. These policy documents do therefore not only show a substantive division within the EU institutions, but do also not indicate which of the two points of view on the scope of mutual recognition of final decisions in criminal matters should be followed - the substantive interpretation of the European Commission or the formal interpretation of the European Parliament.

The final and most important reason why the Commission's definition cannot be blindly used to determine the classification of youth justice at EU level is the context in which the statement was made. By defining the notion of 'criminal matters', the Commission was preparing its answer on the question whether the punishment of legal persons is included in the notion of criminal matters and, consequently, whether foreign judicial decisions on the criminal liability of legal persons should be executed. The Commission's response was eventually affirmative, since 'measures of a non-criminal nature' are also considered to be dealing with criminal matters to the extent that they are necessary to hold legal persons accountable for the criminal offences committed for their benefit by their leading natural persons." 88 The same reservation can be made regarding the reply of the committee on Citizens' Freedoms and Rights, Justice and Home Affairs. After giving its formal definition of criminal matters, the committee applies the definition to the question at stake and confirms that alternative and rehabilitation measures for drug dependants or mentally disabled persons and penalties for legal persons are also considered to be criminal matters, but only insofar as they implement penalties that are imposed in response to criminal offences. Since the scope of criminal matters is specified with respect to other issues than youth justice, no firm conclusions can be drawn regarding the latter.

\subsubsection{Specific scope of mutual recognition instruments without an age refusal ground}

After having determined that no uniform and binding general definition of the notion 'criminal matters' exists at the moment, it is appropriate to analyse the specific scope of the mutual recognition instruments without an age refusal ground. Only the EIO Directive and the freezing orders and confiscation orders Regulation are taken into account, since they will replace the existing freezing orders FD and confiscation orders FD.

As far as the EIO Directive is concerned, article 4 describes the types of proceedings for which an EIO can be issued. Apart from criminal proceedings, ${ }^{89}$ an EIO can be issued in proceedings brought by administrative or judicial authorities in respect of punishable infringements according to the national legislation of the issuing Member State, and where the decision may lead to proceedings before a 'court having jurisdiction in criminal matters'. ${ }^{90}$ The latter is an autonomous concept in EU law that

\footnotetext{
86 Ibid.

87 Committee on Citizens' Freedoms and Rights, Justice and Home Affairs, ' Report of 23 October 2003 with a proposal for a European Parliament recommendation to the Council on procedural safeguards for suspects and defendants in criminal proceedings throughout the European Union' A5-0361/2003.

${ }^{88}$ Commission, 'Communication to the Council and the European Parliament - Mutual Recognition of Final Decisions in Criminal Matters' $\operatorname{COM}(2000) 495$ final, 6.

${ }^{89}$ EIO Directive, article 4 (a).

${ }^{90}$ EIO Directive, article 4 (b) and (c).
} 
should be interpreted as "a court that applies a procedure which satisfies the essential characteristics of criminal procedure, without it being necessary for that court to have jurisdiction in criminal matters alone". ${ }^{91}$ Unfortunately, the ECJ has not seized the opportunity to specify which essential characteristics exactly comprise a criminal procedure, thereby avoiding the hot potato again. In any case, the scope of the EIO Directive not only covers 'pure' criminal proceedings, but also administrative or other judicial proceedings having a criminal dimension. ${ }^{92}$

The scope of the freezing orders and confiscation orders Regulation is limited to freezing orders and confiscation orders that are issued within the framework of proceedings in criminal matters. ${ }^{93}$ Article 1 (4) clarifies that civil and administrative proceedings are excluded from the scope, ${ }^{94}$ because such proceedings cannot be covered on the basis of article 82 (1) TFEU. ${ }^{95}$ However, the Council of the European Union confirmed that national confiscation systems which consist of preventive confiscation that are clearly linked to criminal activities also fall within the scope of the regulation. ${ }^{96}$ In other words, the preventive purpose of the confiscation measure does not lead to an exclusion from the scope of this regulation, as long as there is a link with the crime committed. Proceedings with both administrative and criminal elements, contrary to pure administrative proceedings, are therefore covered by the freezing orders and confiscation orders regulation. This nuance came about as a result of a discussion on the Italian confiscation system, which includes preventive confiscation that is clearly linked to the commission of a crime but not conducted in the course of criminal proceedings. ${ }^{97}$ Some Member States expressed their doubts as to whether such hybrid systems fall under the legal basis of article 82 (1) TFEU. ${ }^{98}$ Italy argued that its system would not fall within the notion of 'criminal proceedings' and therefore be excluded from the proposed regulation. That is why it suggested to adapt the scope to 'proceedings in criminal matters', which in its view covers more national confiscation systems than the notion 'criminal proceedings'. ${ }^{99}$ Although the Council did not express itself on the terminology and the flexibility that goes with it, the scope was adapted for the benefit of Italy. Recital 13 now more specifically states that the regulation applies to all freezing orders and confiscation orders issued within the framework of proceedings in criminal matters and reformulates the latter as 'proceedings in relation to a criminal offence'. In that way, the EU legislator wants to make clear that the scope of the regulation is not limited to orders that result from the list of criminal offences contained in article 3 of Directive 2014/42 on the freezing and confiscation of instrumentalities and proceeds of crime in the European Union, ${ }^{100}$ but also covers orders that are issued without a final conviction. ${ }^{101}$

Both instruments apply not only to purely criminal proceedings, but also cover other types of judicial proceedings that possess criminal law characteristics, which are expressed either by the nature of the court or by the type of infringement of the national legislation. These findings clearly fit into the discourse of the substantive interpretation and do provide insight into how the European legislator understands the criminal concept. However, they do not allow to infer the exact position of youth

\footnotetext{
${ }^{91}$ Case C-60/12 Baláž [2013] ECLI:EU:C:2013:733, para 36 and 42.

92 Labor Klimek, Mutual Recognition of Judicial Decisions in European Criminal Law (Springer 2017), 435.

${ }^{93}$ Freezing orders and confiscation orders Regulation, Art 1 (1).

${ }^{94}$ Freezing orders and confiscation orders Regulation, Art 1 (4).

${ }^{95}$ Council of the European Union, 'Proposal for a Regulation on the mutual recognition of freezing and confiscation orders - Question on the issue of scope' (2017) 12685/17, 2.

${ }^{96}$ Council of the European Union, 'Outcome of the 3564th Council meeting Justice and Home Affair of 12 and 13 October 2017' (2017) $13029 / 17,4$

${ }^{97}$ Council of the European Union, 'Proposal for a Regulation on the mutual recognition of freezing and confiscation orders - Question on the issue of scope' (2017) 12685/17, 2.

${ }^{98}$ Council of the European Union, 'Proposal for a Regulation on the mutual recognition of freezing and confiscation orders - Question on the issue of scope' (2017) 12685/17, 4.

${ }^{99}$ Council of the European Union, 'Proposal for a Regulation on the mutual recognition of freezing and confiscation orders - Revised text following discussion on 4 and 5 September 2017' (2017) 11971/17, 12.

100 Directive 2014/42 of the European Parliament and of the Council of 3 April 2014 on the freezing and confiscation of instrumentalities and proceeds of crime in the European Union [2014] OJ L 127/39.

101 Freezing orders and confiscation orders Regulation, recital 13.
} 
justice in EU criminal law because the statements on the scope of criminal matters were all made in specific contexts and in response to specific issues, none of which were related to minors.

4.4 Scope of application of the procedural rights directives, in particular the Children Directive

The procedural rights directives all declare to be applicable in 'criminal proceedings', without further defining that crucial notion (supra 3.4). The first step in determining their scope of application is therefore to seek guidance in the preambles of the procedural rights directives, of which the recitals are interpretative tools in the EU legal order. Although ECJ case law confirms that recitals are not legally binding, ${ }^{102}$ they can be used to explain the meaning of ambiguous legal provisions. ${ }^{103}$ In case of the Children's Directive, article 1 and 2 specify that the directive applies to children who are suspects or accused persons in criminal proceedings or who are subject to EAW proceedings, ${ }^{104}$ which is further explained in recital 17:

"This Directive should apply only to criminal proceedings. It should not apply to other types of proceedings, in particular proceedings which are specially designed for children and which could lead to protective, corrective or educative measures."

Recital 17 excludes proceedings that are specially designed for children from the notion 'criminal proceedings', so that it is unquestionable that the EU legislator does not adopt a substantive interpretation with regard to the procedural rights instruments. On the contrary, by defining the scope as only criminal proceedings and not any other type of proceedings, the recital rather indicates a classical interpretation. However, that would exclude the youth justice systems of all Member States from the scope, since every youth justice system is specially designed for children and consists of another type of proceedings than the ordinary criminal justice. In that case, the Children Directive would only be applicable in the rather exceptional cases that a minor is subject to ordinary criminal proceedings (supra 4.1).

The explanatory notes of the Commission's proposal that accompany recital 17 provide more clarity and suggest that a formal interpretation should be adopted. They more specifically state that, in certain Member States, children who have committed an act qualified as an offence are not subject to criminal proceedings according to national law. ${ }^{105}$ If these Member States provide for other forms of proceedings which may lead to the imposition of certain restrictive measures, such as protection or education measures, they do not fall within the scope of this Directive. ${ }^{106}$ So according to the EU legislator, the criminal nature of the proceedings depends on its label in the domestic law. This is still a striking limitation given the fact that many Member States do not follow a purely criminal approach when responding to delinquent behaviour of minors, or even formally place youth justice outside the realm of criminal justice. ${ }^{107}$ It fits however in the traditional welfare-justice dichotomy from international juvenile justice literature, i.e. that strong procedural safeguards are of greater importance in criminal proceedings than in educational proceedings, because the focus of the former

\footnotetext{
102 Case C-162/97 Nilsson [1998] ECR I-7477, para 54; Roberto d Luiss-Guido Carli, 'Complexity of EU law in the domestic implementing process' (19th Quality of Legislation Seminar, Brussels, July 2014), 9.

103 Tadas Klimas and Jurate Vaiciukaite, 'The Law of Recitals in European Community Legislation' (2008) Vol 15 ILSA Journal of Int'I \& Comparative Law 1, 13.

${ }^{104}$ Children Directive, art 1-2.

${ }^{105}$ Commission, 'Proposal for a Directive of the European Parliament and of the Council on procedural safeguards for children suspected or accused in criminal proceedings' COM (2013) 822 final, para 16.

106 Ibid.

107 Dorris de Vocht, Michele Panzavolta, Miet Vanderhallen and Marc Van Oosterhout, 'Procedural Safeguards for Juvenile Suspects in Interrogations: A Look at the Commission's Proposal in Light of an EU Comparative Study' (2014) vol. 5 iss. 4 New Journal of European Criminal Law 480, 484-486.
} 
is on the facts and resolving the question of guilt, whereas the focus of the latter is on the person of the offender and finding what measure of (re)education or treatment is in his best interest. ${ }^{108}$

The impact of the Children Directive in each Member State will consequently depend on the classification of the youth justice system under the national legislation. If a Member State formally labels its youth justice system as criminal, the Children Directive technically applies. This might e.g. be the case in the Netherlands, whose youth justice system ('jeugdstrafrecht') provides for rules that are adapted to juvenile offenders, but that are officially part of or embedded in the 'general' criminal law. ${ }^{109}$ When, in contrast, a Member State's rules concerning juvenile offenders are embedded in a youth protection/welfare system, e.g. in Belgium and in Poland, or in administrative proceedings, e.g. in Bulgaria, ${ }^{110}$ the formal approach in recital 17 would have as a result that these Member States are not obliged to transpose the Children Directive. ${ }^{111}$

Although the recital can only be found in the Children Directive, some entities argue that all directives resulting from the Procedural Rights Roadmap should be applied in a similar way to minors. ${ }^{112}$ Although the five other procedural rights directives do not contain explicit provisions on the (non-criminal) nature of youth justice proceedings, their scope is limited by analogy with recital 17 because it is defined in a similar way as the Children Directive, namely 'suspected or accused persons in criminal proceedings'. ${ }^{113}$ The influence of recital 17 therefore extends beyond the Children Directive.

\subsection{Conclusion}

Now that the relevant EU procedural criminal legislation has been analysed, it can be concluded that the EU has not yet given a general, binding, autonomous definition of the criminal concept, ${ }^{114}$ that is expressed in different variants, such as 'criminal responsibility', 'criminal proceedings', 'criminal matters', 'criminal penalty', etc. The findings of the three types of legislation separately do however give some indication on the position of youth justice in EU criminal law.

The first type, mutual recognition instruments with an age refusal ground, could already apply to minors under the most narrow, classical interpretation, because minors can be subject to adult criminal justice, and not youth justice, in two situations. Taking the EAW FD as an example, minors can first of all be surrendered when they have reached the age of criminal majority and consequently are treated under the general criminal law in any case. This situation will not occur often since the ACM is fixed at the age of 18 in almost all Member States (supra 4.1). Second, surrender is possible in case a minor has been transferred to the adult criminal system based on a national exception that lowers the ACM. The Piotrowski case confirms that it is not the intention of the EU legislator to exclude all minors from the principle of mutual recognition, but also adds another two situations in which the EAW FD is

\footnotetext{
108 Eef Goedseels, 'Jeugdrechtmodellen in theorie en praktijk: een empirisch onderzoek naar het discours en de praktijk van Belgische jeugdrechters' (doctoral thesis, KU Leuven 2015), 4-53.

109 M.A.H. Kempen and Jolande uit Beijerse, 'De EU-Richtlijn procedurele waarborgen minderjarige verdachten in het Nederlandse jeugdstrafprocesrecht' (2016) vol. 7 Nederlands tijdschrift voor Europees recht, 230 - 236.

${ }_{110} \mathrm{DCl}$ Belgium, 'Manual for EU Member States: How to ensure the Rights of Children in Conflict with the Law' (2016), 160-161, <http://www.mylawyermyrights.eu/wp-content/uploads/2016/05/MANUAL-FOR-EU-MS_Web_EN.pdf>.

111 Michele Panzavolta, Dorris de Vocht, Marc Van Oosterhout and Miet Vanderhallen (eds), Interrogating Young Suspects: Procedural Safeguards from a Legal Perspective (Intersentia 2015) 375.

$112 \mathrm{DCl}$ Belgium, 'Manual for EU Member States: How to ensure the Rights of Children in Conflict with the Law' (2016), 161, <http://www.mylawyermyrights.eu/wp-content/uploads/2016/05/MANUAL-FOR-EU-MS Web_EN.pdf>; DCI Belgium, 'The role of the youth lawyer in welfare and criminal proceedings in Belgium' (National report, 2017), 27, <https://www.dei-belgique.be/index.php/nospublications/rapports/send/37-rapports/154-national-report-belgium-eng-full-version.html>; Wetsontwerp houdende verdere omzetting van de Richtlijn 2010/64/EU betreffende het recht op vertolking en vertaling in strafprocedures en van de Richtlijn 2012/29/EU tot vaststelling van minimumnormen voor de rechten, de ondersteuning en de bescherming van slachtoffers van strafbare feiten, en ter vervanging van Kaderbesluit 2001/220/JBZ, Parl.St. Kamer 2015-2016, nr. 54-2029/001, 31.

113 Wetsontwerp houdende verdere omzetting van de Richtlijn 2010/64/EU betreffende het recht op vertolking en vertaling in strafprocedures en van de Richtlijn 2012/29/EU tot vaststelling van minimumnormen voor de rechten, de ondersteuning en de bescherming van slachtoffers van strafbare feiten, en ter vervanging van Kaderbesluit 2001/220/JBZ, Parl.St. Kamer 2015-2016, nr. 54-2029/001, 31.

${ }^{114}$ André Klip, European Criminal Law: An Integrative Approach (Intersentia 2009), 158.
} 
applicable to minors. The ECJ first of all stretches this classical interpretation by favouring the principle of mutual recognition and declaring a potential waiver in the executing Member State sufficient to be criminally responsible. It therefore allows the surrender of a minor who has not been transferred to the adult criminal system yet, but who has reached the age from which on such a transfer is technically possible under the legislation of the executing Member State. The ECJ moreover seems to adopt a formal interpretation with regard to the concept of criminal responsibility, as a result of which surrender would also be possible in case a minor has reached the age to be subject to measures taken under the youth justice system of the executing Member State, which are considered to have a criminal nature by that Member State.

With regard to the mutual recognition instruments without an age refusal ground, the only clarifications available date back to before any framework decision was adopted or concern other issues than youth justice. They more specifically answer the question to what extent administrative proceedings or proceedings against legal persons are also considered to be 'proceedings in criminal matters'. In that context, the European Commission's communication from 2000, the EIO Directive and the freezing orders and confiscation orders Regulation make some statements that perfectly fit into the discourse of the substantive interpretation. Although that does not guarantee a substantive approach with regard to youth justice as well, it would be consistent that a mutual recognition instrument that does not contain a basis for excluding certain minors from its scope, should apply to these minors.

Finally, the only youth justice systems that have to comply with the requirements laid down in the procedural rights directives, are the ones that are formally labelled as criminal according to the national legislation of their Member State. This is the result of recital 17 of the Children Directive, which indicates that the EU legislator adopts a formal interpretation and excludes protective and educational youth justice proceedings from its scope of 'criminal proceedings'.

In the few clues that the EU institutions leave behind on the position of youth justice in EU criminal law, it can be deduced that, in general and for the sake of convenience, they leave the interpretation of the criminal concept to the Member States themselves. The inevitable consequence of such a formal approach is a non-homogeneous implementation of criminal law instruments across the EU, since the application of the instrument depends on the domestic legislation of each Member State. This might to a certain extent be justified in case judicial cooperation is the purpose of an EU criminal law instrument, but more fundamental questions arise when such an instrument aims to provide procedural safeguards to a particular vulnerable group of suspects. Although the welfare-justice dichotomy explains why the emphasis on procedural safeguards is stronger in punitive youth justice systems than in welfare-oriented youth justice systems, it does not justify that the qualification of youth justice systems as one or the other, and thus the minimum level of procedural guarantees, is left to the discretion of national legislation. ${ }^{115}$ One could therefore argue that the interpretation of the criminal concept should differ according to the finality of the EU instrument and that a broader interpretation of the notion 'criminal' is appropriate when EU legislation provides procedural protection. That view is however contradicted by the preparatory documents of the freezing orders and confiscation orders Regulation, which suggested that the concept 'proceedings in criminal matters' from article 82 (1) TFEU, which is the legal basis of the mutual recognition instruments, is more flexible than the concept 'criminal proceedings' from article 82 (2) (b) TFEU, which is the legal basis of the procedural rights directives. ${ }^{116}$ It therefore seems like no consistency can be found here either, especially as the scope of the procedural rights directives includes both criminal proceedings and EAW proceedings (supra 3.4), which makes it unlikely that the criminal concept of the mutual recognition instruments should be interpreted in a different way than the one of the procedural rights instruments.

\footnotetext{
115 This is confirmed by Blokhin v Russia, see 5.1 .

${ }^{116}$ Council of the European Union, 'Proposal for a Regulation on the mutual recognition of freezing and confiscation orders - Revised text following discussion on 4 and 5 September 2017' (2017) 11971/17, 12.
} 
5 The interpretation of criminal concepts outside the EU context

It should be clear by now that there is no coherent approach within the EU regulatory framework on the criminal concept, especially with regard to youth justice. The lack of clarity due to the reticence of EU institutions are in stark contrast to the unequivocal meaning that institutions outside the EU attribute to similar concepts. The United Nations and the Council of Europe more specifically adopt a substantive interpretation of the criminal concept, which raises some interesting issues in their relationship with the EU.

\subsection{Substantive interpretation of the United Nations and the Council of Europe}

Article 40 (3) (a) of the United Nations Convention on the Rights of the Child (UNCRC) requires the State Parties to establish a minimum age below which children shall be presumed not to have 'the capacity to infringe the penal law', which is universally known as the minimum age of criminal responsibility (MACR). ${ }^{117}$ According to this description, the term 'criminal' in the concept of the MACR refers to the nature of the infringement, rather than to the nature of the youth justice system. The national classification of the youth justice system is therefore irrelevant, as long as it reacts to the violation of the national criminal law. Contrary to the EU, the UNCRC clearly adopts a substantive interpretation as far as the MACR is concerned. One could say that within the concept of 'criminal responsibility', the EU rather puts the emphasis on criminal, while the UNCRC puts it on responsibility.

The European Court of Human Rights (ECtHR) is another institution that takes a substantive approach with regard to a criminal concept. ${ }^{118}$ It more specifically interprets the notions 'criminal charge' and 'criminal offence' within article 6 of the European Convention for the Protection of Human Rights and Fundamental Freedoms (ECHR) in a broad way. Following its judgment in Engel and Others $v$ Netherlands, the ECtHR put forward three criteria for determining the criminal nature of an offence: the legal classification of the offence under domestic law, the very nature of the offence, and the degree of severity of the penalty. ${ }^{119}$ This case law thus develops an autonomous meaning of the criminal notion, thereby looking beyond the national label of the charge. A sanction which is formally intended to prevent or to remedy, but which is substantially dissuasive or repressive, is consequently not exempted from the fair trial safeguards of article 6 ECHR. As a consequence, the criminal limb of article 6 ECHR has consistently been applied to several youth justice cases. ${ }^{120}$ In the Blokhin $v$ Russia case, a minor was questioned without adequate legal guarantees and subsequently deprived from his liberty on the basis of an administrative order. ${ }^{121}$ Despite the formally administrative nature of the national proceedings, the ECtHR considers them to be criminal in the meaning of article 6 ECHR, and it explains exactly why:

"On no account may a child be deprived of important procedural safeguards solely because the proceedings that may result in his deprivation of liberty are deemed under domestic law to be protective of his interests as a child and juvenile delinquent, rather than penal.". ${ }^{122}$

\footnotetext{
117 UN Committee on the Rights of the Child, 'General comment No. 24 (2019) on children's rights in the child justice system', nr. 8, $<$ http://docstore.ohchr.org/SelfServices/FilesHandler.ashx?enc=6QkG1d\%2fPPRiCAghKb7yhsqlkirKQZLK2M58RF\%2f5FOvEnG3OGKUxFivhT oQfjGxYjV05tUAlgpOwHQJsFPdJXCiixFSrDRwow8HeKLLh8cgOw1SN6vJ\%2bfORPR9UMtGkA4>.

118 Michele Panzavolta, Dorris de Vocht, Marc Van Oosterhout and Miet Vanderhallen (eds), Interrogating Young Suspects: Procedural Safeguards from a Legal Perspective (Intersentia 2015) 375.

${ }^{119}$ Engel and Others $v$ the Netherlands App no 5100/71, 5101/71, 5354/72, 5370/72 (ECtHR, 8 June 1976), §82.

${ }_{120}$ Nortier $v$ the Netherlands App no 13924/88 (ECtHR, 24 August 1993); T. and V. $v$ UK App no 24724/94, 24888/94 (ECtHR, 16 December 1999); S.C. v UK App no 60958/00 (ECtHR, 15 June 2004); Salduz v Turkey App no 36391/02 (ECtHR, 27 November 2008); Panovits v Cyprus App no 4268/04 (ECtHR, 11 December 2008); Güveç v Turkey App no 70337/01 (ECtHR, 20 January 2009); Adamkiewicz v Poland App no 54729/00 (ECtHR, 2 March 2010); Kuptsov and Kuptsova v Russia App no 6110/03 (ECtHR, 3 March 2011); J.M. v Denmark App no 34421/09 (ECtHR, 13 November 2012); Blokhin v Russia App no 47152/06 (ECtHR, 14 November 2013).

${ }^{121}$ Blokhin v Russia App no 47152/06 (ECtHR, 14 November 2013).

$122 \mathrm{lbid}, \S 196$.
} 
The ECtHR thus even considers the more welfare-oriented and protection-oriented youth justice systems as criminal, because their educative and correctional measures can also consist of a deprivation of liberty in closed settings, sometimes even for an indeterminate period of time and can therefore be as afflictive as a criminal penalty. ${ }^{123}$ In that way, any division between youth justice systems based on national labels is removed, which is essential to allow everyone to invoke the rights on a fair trial provided for by Article 6 ECHR in the same way.

\subsection{Consequences of the different interpretations at different levels}

For the purposes of this article, three interesting issues are highlighted following the findings that the criminal concept is used at different policy levels (international, supranational and national) in different legal sources (legislation, case law and legal doctrine), ${ }^{124}$ without necessarily being interpreted in the same way.

(1) It is first of all confusing that the EU increasingly interacts with other legal levels, which also use a criminal concept but potentially interpret it differently. In addition, the bodies at inter-, supra- and national level are often not aware of the fact that they attach different meanings to a same concept, since they rarely make explicit in which way they interpret it and sometimes do not even apply it consistently themselves. As a consequence, the interaction between the $\mathrm{EU}$ and another legal order sometimes leads to contradictory situations. Article 40 (3) UNCRC for instance requires State Parties to promote the establishment of laws and procedures specifically applicable to children in conflict with the law. Since all EU Member States are also State Parties to the UNCRC, they are bound to this obligation. It is therefore no surprise that the procedural rights directives acknowledge that the Member States are parties to the UNCRC, ${ }^{125}$ and also declare to promote the rights of the child, taking into account the Guidelines of the Council of Europe on child-friendly justice. ${ }^{126}$ The Guidelines, in turn, confirm Article 40 (3) UNCRC by recommending the Member States to establish specialist courts (or court chambers), procedures and institutions for children in conflict with the law. ${ }^{127}$ However, after the endorsement of these international standards, youth justice systems that are separate from adult criminal law and are adopted to children should, by means of recital 17 of the Children Directive, not have to transpose the legal safeguards of the Children Directive into national law (supra 4.4). Knowing that youth justice systems are established in response to the UNCRC demand of specialisation and adaptation towards minors, this recital certainly undermines the Member States' international obligations.

Another example is that the Procedural Rights Roadmap is an initiative that gained momentum after the ECtHR Salduz case ${ }^{128}$, in which the Grand Chamber ruled that the right to access to a lawyer under article 6 (3) of the ECHR also applies before the first interrogation by the police of the suspect, in casu a minor. ${ }^{129}$ It is a matter of friction that ECtHR case law, known for its broad interpretation of the criminal concept, inspired the EU to draw up a framework to grant procedural rights to minors, but in which many minors cannot benefit from those rights because of a more narrow interpretation of the criminal concept.

(2) A second issue is that the lack of conceptual coherency within the EU also leads to confusion in legal doctrine, which is best illustrated by how the Belgian MACR is dealt with by authors. In international comparison tables, three possible Belgian MACRs can be distinguished, namely 18, 16

\footnotetext{
${ }_{123}$ Michele Panzavolta, Dorris de Vocht, Marc Van Oosterhout and Miet Vanderhallen (eds), Interrogating Young Suspects: Procedural Safeguards from a Legal Perspective (Intersentia 2015) 376.

${ }^{124}$ For a discussion on the fragmentation and overlap of international standards in juvenile justice, see: Sabien Hespel, Johan Put and Marjan Rom, 'Navigating the Maze. The Interrelation of International Legal Norms, with Illustrations from International Juvenile Justice Standards' (2012) 6 HR\&ILD 2, 329.

125 Children Directive, recital 3.

${ }^{126}$ Children Directive, recital 7.

${ }^{127}$ Council of Europe, 'Guidelines of the Committee of Ministers of the Council of Europe on child-friendly justice' (2010), Guideline 63.

${ }^{128}$ Salduz v Turkey App no 36391/02 (ECtHR, 27 November 2008).

129 Ed Cape, 'Procedural rights and mutual co-operation' (2018).
} 
and 12 years. The European Commission itself ${ }^{130}$ as well as the majority of leading authors in the field of juvenile justice ${ }^{131}$ determine that the MACR is 18. This is because Belgium's youth justice system does in principle not allow juvenile offenders to be prosecuted or convicted under the traditional criminal law rules, but instead provides for a separate welfare-oriented system of protective and educational measures. In this view, there seems to be no difference between the MACR and the ACM. The second point of view in the literature fixes the Belgian MACR at the age of 16 , since it is theoretically possible from this age onwards that minors are transferred to ordinary criminal proceedings. ${ }^{132}$ This group has gained more support since the Piotrowski judgment. The third, and least common, view in the comparative literature is that the MACR in Belgium is 12 years, ${ }^{133}$ on the basis of the description of the MACR by Article 40 (3) (a) UNCRC. This is in our opinion the correct interpretation, especially since a more sanction-oriented 'juvenile delinquency law' has entered into force in the Flemish Community in 2019 which explicitly fixes the Flemish AMCR at the age of $12 .{ }^{134}$ The Dutch MACR, on the contrary, is fixed at 12 years in every comparison table, ${ }^{135}$ even though the Dutch youth justice system has approximately the same type of measures and age limits as the Belgian youth justice system and has specialised judges and institutions as well. The main difference is that the Dutch youth justice system is labelled as 'juvenile criminal law' and is embedded in the national criminal laws, whereas the Belgian system is given a welfare label and is deliberately worked out in a separate act. The confusion about the Belgian MACR consequently seems to exist purely because of the national qualification, which might be disputed as a basis for determining the MACR.

(3) The absence of a coherent conceptual framework within the EU, finally raises the question whether the criminal concept of the ECtHR should be adopted. After all, many youth justice systems have removed the formal 'criminal' label of their youth justice systems, whereas they still preserve a substantive punitive nature. ${ }^{136}$

The procedural rights directives themselves recall that Member States are bound by ECHR, ${ }^{137}$ and therefore also by the judgments of the ECtHR. ${ }^{138}$ Moreover, the ECJ issued some judgments in which it explicitly adopts the 'Engel' criteria to decide whether certain measures are criminal penalties in the meaning of the relevant EU legislation. It more specifically states that criminal law is characterised by its dissuasive or deterrent nature and not primarily by its classification in domestic law. ${ }^{139}$ The ECJ has thereby aligned its case law with the opinions of Advocates-General, who had been calling for the

\footnotetext{
${ }^{130}$ Commission, 'Commission Staff Working Document - Impact Assessment accompanying the document Proposal for a Directive of the European Parliament and of the Council on procedural safeguards for children suspected or accused in criminal proceedings' SWD (2013) 480 final, 35.

131 Ido Weijers, Jeugdige dader, volwassen straf? (Kluwer 2006), 52; Josine Junger-Tas and Frieder Dünkel (eds), Reforming Juvenile Justice (Springer 2009), 221; Council of Europe, European Rules for juvenile offenders subject to sanctions or measures (Council of Europe Publishing 2009), 116; Frieder Dünkel, Joanna Grzywa, Philip Horsfield and Ineke Pruin (eds), Juvenile Justice Systems in Europe: Current Situation and Reform Developments, vol 4 (Forum Verlag 2010), 1793; Franklin E. Zimring, Máximo Langer and David S. Tanenhaus (eds), Juvenile Justice in Global Perspective (New York University Press 2015), 22.

132 Neal Hazel, 'Cross-national comparison of youth justice' (Youth Justice Board, 2008) 30; Ido Weijers, 'The Minimum Age of Criminal Responsibility in Continental Europe Has a Solid Rational Base' (2016) 67 N. Ir. Legal Q. 301, 302.

${ }^{133}$ Ido Weijers and Frank Imkamp (eds), Jeugdstrafrecht in internationaal perspectief (Boom Juridische uitgevers 2008), 270-271; Don Cipriani, Children's Rights and the Minimum Age of Criminal Responsibility: A Global Perspective (Ashgate 2009), 98; DCI Belgium, 'Manual for EU Member States: How to ensure the Rights of Children in Conflict with the Law' (2016), 25-26, <http://www.mylawyermyrights.eu/wpcontent/uploads/2016/05/MANUAL-FOR-EU-MS Web EN.pdf>.

${ }^{134}$ Article 4 §2 of the Flemish Decree on Juvenile Delinquency; see also Jantien Leenknecht, Johan Put and Katrijn Veeckmans, 'Age limits in youth justice: a comparative and conceptual analysis' (2020) Erasmus Law Review (forthcoming).

${ }^{135}$ Some examples are: Neal Hazel, 'Cross-national comparison of youth justice' (Youth Justice Board, 2008) 30; Council of Europe, European Rules for juvenile offenders subject to sanctions or measures (Council of Europe Publishing 2009), 116; Frieder Dünkel, Joanna Grzywa, Philip Horsfield and Ineke Pruin (eds), Juvenile Justice Systems in Europe: Current Situation and Reform Developments, vol 4 (Forum Verlag 2010), 1793; Ido Weijers, 'The Minimum Age of Criminal Responsibility in Continental Europe Has a Solid Rational Base' (2016) 67 N. Ir. Legal Q. 301 , 302.

136 Dorris de Vocht, Michele Panzavolta, Miet Vanderhallen and Marc Van Oosterhout, 'Procedural Safeguards for Juvenile Suspects in Interrogations: A Look at the Commission's Proposal in Light of an EU Comparative Study' (2014) vol. 5 iss. 4 New Journal of European Criminal Law 480, 486.

137 Children Directive, recital 3.

${ }^{138}$ Directive 2010/64/EU of the European Parliament and of the Council of 20 October 2010 on the right to interpretation and translation in criminal proceedings [2010] OJ L280/1, recital 33; DCI Belgium, 'The role of the youth lawyer in welfare and criminal proceedings in Belgium' (National report, 2017), 27.

${ }^{139}$ Case C-489/10 Łukasz Marcin Bonda [2012] ECR I-00319, para 37; Case C-617/10 Akerberg Fransson [2013] ECR I-00105, para 35.
} 
ECtHR case law to be applied in the EU framework in the absence of an own definition. ${ }^{140}$ Some authors therefore argue that the 'Engel' criteria have become part of the ECJ dogmatism and can consequently be imposed on the Member States, ${ }^{141}$ as national public officials are expected to apply the ECJ's approach to interpretation. ${ }^{142}$

However, there are some objections to the automatic adoption of the ECtHR's substantive interpretation of the criminal concept within the EU framework. First, the judgments in which the ECJ adopts the Engel criteria did not concern youth justice matters, but constituted an assessment of the criminal nature respectively of administrative measures as a result of an incorrect declaration of agricultural areas ${ }^{143}$ and of tax penalties ${ }^{144}$. As long as the ECJ is not asked a preliminary question or does not spontaneously clarify (cf. Piotrowski) whether a youth justice measure should be qualified as a criminal penalty within EU legislation, it remains unclear whether it would apply the Engel criteria in order to make its judgment. Second, the EU has still not acceded to the ECHR because the Draft Accession Agreement was deemed to be contrary to the condition of article 6 (2) TEU that the EU's competences as defined in the Treaties shall not be affected. ${ }^{145}$ As a consequence, the ECHR and the case law of the ECtHR cannot give substance to the EU competence in criminal matters and definitely cannot broaden that competence. This is confirmed by recital 13 of the freezing orders and confiscation orders Regulation, which states that 'proceedings in criminal matters' is an autonomous EU concept, notwithstanding the ECtHR case law. ${ }^{146}$ That clearly reflects the idea that the EU is an autonomous legal order, which does not simply adopt the interpretation of concepts that is given in another legal order.

\section{Conclusion}

This article started off by showing that in the historical development of the EU as a major player in the fight against cross-border crime, little attention was paid to cross-border juvenile delinquency. This is reflected in the description of the EU competences, since the Treaties do not provide a ground of competence for youth justice explicitly conferred upon the Union. The question arose whether the area of youth justice is part of the EU competence of judicial cooperation in criminal matters and whether the existing EU instruments in criminal matters also apply to juvenile offenders.

No general answer could be given to this question for a number of reasons, not least the absence of an autonomous definition of the notion 'criminal'. In general, few statements are to be found on the meaning of a concept that is very essential in the expanded EU competence of judicial cooperation. Although the EU institutions took a stance on the inclusion of e.g. civil and administrative procedures and legal persons in the criminal concept (cf. the EC communication from 2000, the EC Handbook on how to issue and execute an EAW, the EIO Directive and the freezing orders and confiscation orders regulation), these statements were often open to interpretation and were moreover made in contexts unrelated to youth justice. Therefore, no firm general conclusions can be drawn in the area of youth justice.

\footnotetext{
${ }^{140}$ Case C-273/90 Meico-Fell v Hauptzollamt Darmstadt [1991] ECR I-5583, Opinion of AG Van Gerven, para 10; Case C-240/90 Germany v Commission [1992] ECR I-5383, Opinion of AG Jacobs, para 11; Case C-356/97 Molkereigenossenschaft Wiedergeltingen [2000] ECR I-5461, Opinion of AG Saggio, para 50; Case C-62/06 Fazenda Pública - Director Geral das alfândegas/ZF Zefeser - Importaçao e Exportaçao de Produtos Alimentares Lda [2007] ECR I-11995, Opinion of AG Trstenjak, para 56; Case C-440/05 Commission v Council [2007] ECR I-9097, Opinion of AG Mazák, para 71; Case C-489/10 Łukasz Marcin Bonda [2012] ECR I-00319, Opinion of AG Kokott, para 42-46..

${ }^{141}$ Alessandro Rosanò, 'The concept of criminal law in the opinions of the Advocates General - Justification of Punitive Powers and Human Rights' (2016) vol. 7 iss. 1 New Journal of European Criminal Law 59, 73.

${ }_{142}$ Roberto Baratta and Luiss-Guido Carli, 'Complexity of EU law in the domestic implementing process' (19 ${ }^{\text {th }}$ Quality of Legislation Seminar, Brussels, July 2014), 7.

${ }^{143}$ Case C-489/10 Łukasz Marcin Bonda [2012] ECR I-00319, para 37.

${ }^{144}$ Case C-617/10 Akerberg Fransson [2013] ECR I-00105, para 35.

145 Opinion 2/13 pursuant to Article 218 (11) TFEU [2014] ECLI:EU:C:2014:2454, para 258.

${ }^{146}$ Regulation 2018/1805 on the mutual recognition of freezing orders and confiscation orders, recital 13.
} 
That is why this article subsequently analysed the scope of different types of EU criminal law instruments separately. It showed that the Piotrowski case and recital 17 of the Children Directive are the most important sources of interpretation, because they are the only recent, authoritative sources that respectively address the application of the mutual recognition principle and the procedural rights in criminal proceedings to minors.

In the Piotrowski case, the ECJ mainly avoids making general statements about the meaning of the age refusal ground in mutual recognition instruments, but nevertheless stretches the classic interpretation and seems to favour a formal interpretation of the notion 'criminal responsibility'. As a result, surrender of minors is not only possible when they are already subject to the adult criminal system, but also when they have reached the age from which on a transfer to the adult criminal system is technically possible under the legislation of the executing Member State or when they have reached the age from which on the executing Member State state can apply its youth justice system, which is considered to have a criminal nature according to that state. Consequently, only national systems that keep their youth justice officially outside criminal justice on the basis of its protective or administrative elements are able to refuse the surrender of a minor who is too young to be held responsible under their youth justice system.

With regard to the procedural rights directives, recital 17 of the Children Directive indicates that the EU legislator adopts a formal interpretation with respect to this type of legislation. It more specifically excludes protective and educational youth justice proceedings from its scope of 'criminal proceedings', so that the only youth justice systems that have to comply with its requirements are the ones that are formally labelled as criminal according to the national legislation of their Member State. Not only is it contradictory that the instruments aimed at safeguarding the procedural rights of EU citizens and implementing international obligations would have the most narrow scope, it could moreover be questioned whether it is justified that Member States do not have to transpose minimum guarantees purely because they decide that their youth justice proceedings do not have a criminal nature.

The hands-off approach of the EU institutions in respect of youth justice highly contrasts with the clear and expressed positions of other international bodies in that regard, namely the substantive interpretation of the minimum age of criminal responsibility (MACR) by the UNCRC on the one hand and of the notion 'criminal charge' by the ECtHR on the other hand. As a result of the latter, minors who are subject to youth justice proceedings can also benefit from the right on a fair trial as laid down in article $6 \mathrm{ECHR}$. Although the EU does not necessarily need to adopt the same interpretation as these other organisations, the absence of a coherent conceptual framework within the EU is problematic, as was demonstrated by means of three examples.

The only way to create a genuine area of freedom, security and justice, where the mutual recognition of judicial decisions and the minimum procedural guarantees are implemented as effectively as possible, is to create transparency and make sure that all parties have the same understanding of the criminal concept that is the basis for judicial cooperation throughout the Union. The development of coherent terminology does however not necessarily preclude youth justice systems from judicial cooperation at EU level. After all, the finality of certain EU criminal law instruments seem to be in the same line as international children's rights and the ratio legis of many youth justice systems, i.e. the resocialisation of a juvenile offender and taking measures in the interest of that minor. It is time for the EU to take a shared and consistent stand on the meaning of the criminal concept and the in- or exclusion of youth justice, thereby taking into account the specificity of youth justice systems. In that way, the reflection in this article will hopefully become redundant in the future. 